\section{Idea Group REFERENCE}

The Premier Reference Source for Information Science and Technology Research

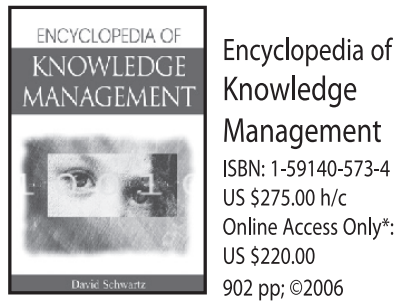

"It is a recommended reference work for all knowledge management (KM) libraries and any course dealing with KM."

- International Journal of Knowledge Management, Vol. 2(3)

Encyclopedia of

Distance

\section{Learning}

ISBN: 1-59140-555-6

US $\$ 995.00 \mathrm{~h} / \mathrm{c}$

Online Access Only*:

US $\$ 796.00$

4-volume set

2,418 pp; $\odot 2005$

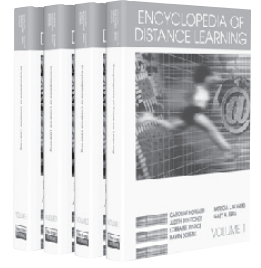

"This encyclopedia is an excellent reference tool for college, university, large public, or special libraries."

- CHOICE, October 2005

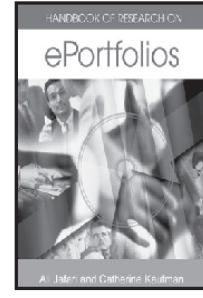

Handbook of Research on ePortfolios

ISBN: 1-59140-890-3

US $\$ 195.00 \mathrm{~h} / \mathrm{c}$

Online Access Only*

US $\$ 156.00$

$648 \mathrm{pp} ; \odot 2006$

"This volume is accessible and likely to be a reference guide for years to come."

- Dr. Lev Gonick

Case Western Reserve University, USA

Free institution-wide online access with the purchase of a print copy!

*Online access is for libraries and is good for life of edition

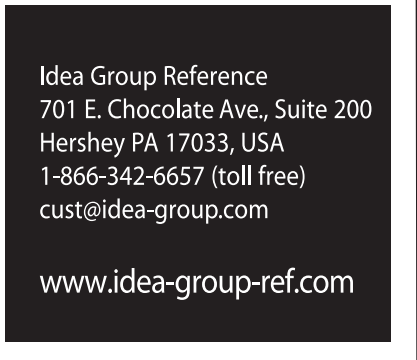

\title{
Is this a
}

\section{teaching machine?}

\author{
By Jonathan Paver and Rebecca P. Butler
}

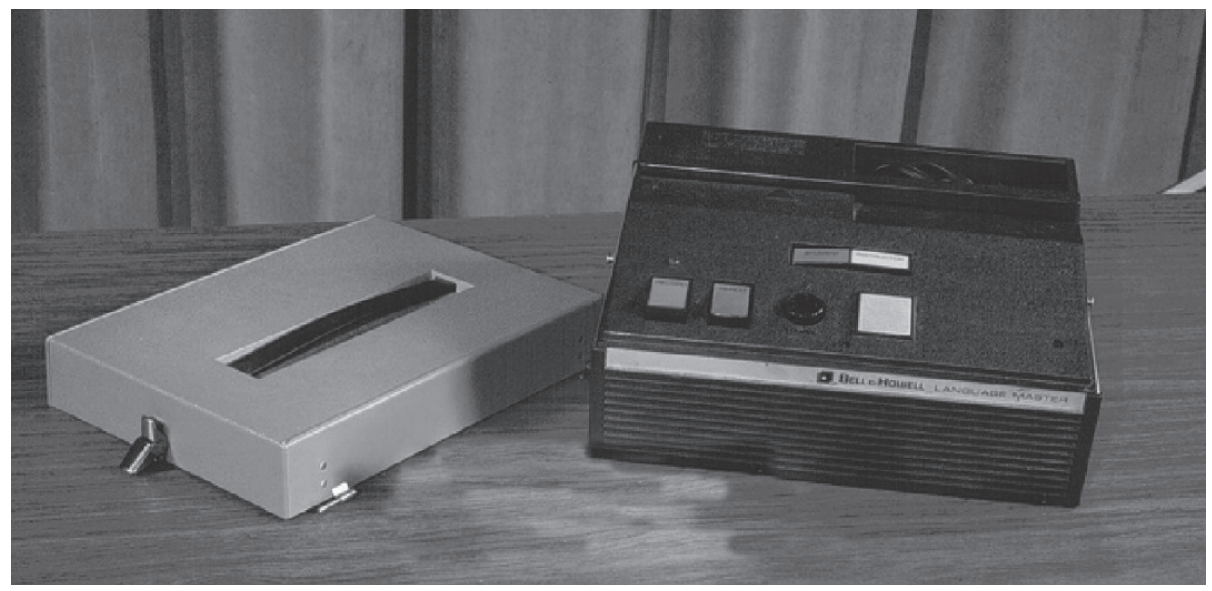

The Bell and Howell Language Master Lee and Lida Cochran AECT Archives Blackwell Museum of Education, Northern Illinois University, 1999

$\mathbf{T}$ he Bell and Howell Language Master was designed to provide students with auditory and visual language learning experiences. This machine used pre-printed cards to make available self-paced individualized instruction in a number of subject areas. . Each of the cards contained a magnetic stripe with recorded audio information that corresponded to the card's printed information.

Bell and Howell began development of language materials and equipment that would eventually become the Language Master, as early as 1966 ("Bell and Howell Company," 2009). A program would normally include, in addition to the subject cards, worksheet spirit duplicating masters, test cards, manipulatives, a teacher's manual, and a storage container. ("Response to Office Action, October 25, 1974," 2009).

\section{References}

Application. (2009). Retrieved from http:// tmportal.uspto.gov/external/portal/!ut/p/ kcxml/04_Sj9SPykssy0xPLMnMz0v-
M0Y_QjzKLN4r3CQXJgFieAfqRqCLG pqgiBvGOcIEgfW99X4_83FT9AP2C3N DQiHJHRQDD419W/delta/base64xml/ L01DU01KQ1RPN29na21DU1Evb0tv U U F B S V F n a k Z J Q U F R a E N F S VFqR0VKemdBIS80SkZpQ28wZWgxaWNvblFWR2hkLXNJZDJFQSEhLzdfMF9GTC81L3NhLmdvdi51c3B0by50b3cuYWN0aW9ucy5EZXRhaWxWaWV3QWN0aW9u\#

Bell and Howell Company. (2009). Retrieved from http://www.answers.com/topic/belland-howell-company

Lee and Lida Cochran AECT Archives. (1999). The Bell and Howell Language Master. DeKalb, Illinois: Blackwell Museum of Education, Northern Illinois University. Retrieved from http://www.cedu.niu.edu/ blackwell/multimedia/high/library.html

Response to Office Action, October 25, 1974. (2009). Retrieved from http://tmportal. uspto.gov/external/portal/!ut/p/kcxml/04_ Sj9SPykssy0xPLMnMz0vM0Y_QjzKLN4r 3CQXJgFieAfqRqCLGpqgiBvGOcIEgfW9 9X4_83FT9AP2C3NDQiHJHRQDD419W/ delta/base64xml/L0lDU01KQ1RPN29na21DU1Evb0tvUUFBSVFnakZJQUFRaENFSVFqR0VKemdBIS80SkZpQ28wZWgxaWNvblFWR2hkLXNJZDJFQSEhLzdfMF9GTC81L3NhLmdvdi51c3B0by50b3cuYWN0aW9ucy5EZXRhaWxWaWV3QWN0aW9u\# 